\title{
Sikap Jamaah Masjid \\ Terhadap Tradisi Puji-Pujian Sebelum Sholat Studi Kasus Jamaah Masjid di Desa Giling dan Kelurahan Sumurboto
}

\author{
Nur Fauzan Ahmad \\ Fakultas Ilmu Budaya Universitas Diponegoro \\ fazwan.268@gmail.com
}

\begin{abstract}
Puji-pujian is the recitation of solawat, dhikr and prayer coupled with Javanese sair-sair sung to await the arrival of praying in congregation at mosque or langgar. This paper discusses the waning of the tradition of praise in society. The research was conducted in Desa Giling, Subdistrict Pabelan, Semarang Regency and Kelurahan Sumurboto, Banyumanik Sub-District, Semarang City. The existence of this tradition began to fade due to the entry and development of movements that seek to purify Islam. The party that supports this tradition is from NU culture. They consider this practice good because it has a basis, and has many benefits da'wah. Who refuses to regard praise as an unclear practice of guidance and potentially disturbing the congregation of other worshipers.

Keywords. Singiran, pujian, attitude of mosque worshipers.
\end{abstract}

\section{Intisari}

Puji-pujian adalah bacaan solawat, dzikir dan doa yang dirangkai dengan sair-sair Jawa yang dilantunkan untuk menunggu datangnya sholat berjamaah di masjid atau langgar. Tulisan ini membicarakan gejala memudarnya tradisi pujian di masyarakat. Penelitian dilakukan di desa Giling, Kecamatan Pabelan Kabupaten Semarang dan kelurahan Sumurboto Kecamatan Banyumanik Kota Semarang. Keberadaan tradisi ini ini mulai memudar. Masuk dan berkembangnya gerakan yang berusaha memurnikan Islam telah menggeser tradisi ini. Pihak yang mendukung tradisi ini adalah dari kultur NU. Mereka menganggap amalan ini baik karena memang ada dasarnya, dan mempunyai banyak manfaat dakwah. Sedang yang menolak menganggap pujian merupakan amalan yang tidak jelas tuntunannya dan mengganggu kekhusukan jamaah lain.

Kata kunci. Singiran, pujian, sikap jamaah masjid.

\section{Pendahuluan}

Kehidupan manusia tidak bisa dipisahkan dengan seni. Bagi manusia seni merupakan alat untuk mengungkapkan pengalaman kehidupannya terhadap realitas kejiwaan yang sangat komplek. Dalam mengungkapkan pengalaman terhadap realitas jiwa, manusia mengunakan simbol yang berbeda. Pengalaman yang sederhana dan dapat digambarkan secara logikakan diungkapkan dengan bahasa yang terdiri dari susunan kata-kata maupun isyarat (bahasa 
tubuh). Sebaliknya, jika pengalaman terhadap realitas tersebut berfisat komplek, maka manusia cenderung mengepresikannya melalui seni.

Hal itu juga berlaku bagi muslim di Jawa. Tradisi bersastra di kalangan muslim Jawa tumbuh dan berkembang sejalan dengan perkembangannya. Tradisi yang bisa berwujud tradisi lisan dan tradisi tulisan ini merupakan ekspresi budaya masyarakat kolektif. Tradisi tulisan berkembang pada masyarakat modern yang sudah mengenal tulisan. Sementara tradisi lisan berkembang di kalangan masyarakat tradisional yang belum mengenal tulisan, seperti di pedesaan biasanya disebarkan dari mulut ke mulut. Namun tradisi ini juga berkembang di masyarakat kota walaupun peranannya relatif kecil dan kurang signifikan (Hutomo, 1991). Tradisi lisan dan tulisan saling berpengaruh satu sama lain. Ada kalanya berkembang bermula dari tradisi tulis yang dilisankan, ada kalanya tradisi lisan dituliskan. Ada yang murni merupakan tradisi lisan.

Wujud tampilan khas Islam Jawa dapat dilihat dari ragam tradisi (ritual) yang masih berlangsung hingga sekarang seperti berbagai bentuk upacara slametan dan ekspresi estetik berupa kreatifitas seni islami. Ekspresi seni tersebut dapat disaksikan dalam bentuk seni suara/ musik, sastra atau pertunjukan (Amin, 2000: viii). Salah satu tradisi (ritual) dalam bentuk ekspresi estetik yang terkenal di masyarakat muslim Jawa adalah pujian di masjid/ langgar.

Pujian adalah lantunan solawat dan berbagai nasehat serta doa yang dilagukan yang dikumandangkan untuk menunggu datangnya solat berjamaah setelah kumandang adzan di masjid/ langgar. Senandung itu dimaksudkan untuk memanggil jamaah lain yang masih di rumah untuk segera mendatangi masjid untuk mendirikan sholat.

Kegiatan puji-pujian juga bisa menarik minat masyarakat khususnya anak-anak untuk berbondong-bondong menuju masjid dan bersama-sama melantunkan lagu yang berisi pujipujian. Tradisi ini berkembang khususnya di masjid dan musholla pada masyarakat khususnya di lingkungan nahdliyyin. Dari tradisi pujian di masjid atau langgar ini bakat seni seni suara khsususnya tilawahnya diasah hingga banyak di antara mereka mahir dalam seni baca Al Quran. Namun tradisi pujian ini saat ini mulai memudar.

Kajian tentang pujian ini sudah banyak dilakukan, misalnya Syi'iran dan Transmisi Ajaran Islam di Jawa, karya M. Mukhsin Jamil, dkk. (2010). Di dalam buku tersebut tradisi pujian di masjid/ langgar disinggung sekilas dan tidak dibahas dalam tema khusus. Pujian sebagai praktek lokal belum dibahas dalam buku tersebut. Walaupun demikian buku ini menjadi penting untuk referensi dalam penelitian tradisi pujian. Jazim 
Hamidi dan Asyhadri Abta (2005) telah mengumpulkan syi'iran hasil karya para ulama/kiai dalam Syi'iran Kiai-Kiai berisikan tentang sya'ir syi'iran-syi'iran, namun tidak menyinggung tradisi pujian. Muhammad Yunus Bakhtiar Rifai tahun 2003 membuat penelitian dalam tesisnya berjudul "Makna Tradisi Pujian Bagi Masyarakat Dusun Kajangan Kelurahan Sonorejo Kabupaten Blora (Suatu Pendekatan Antropo-Sufistik)” yang mengurai permasalahan terkait dengan ragam sya'ir pujian, deskripsi pujian, makna pujian yang hidup dan dipahami masyarakat Kajangan dan makna tasawuf yang terdapat di dalamnya.

\section{Metode}

Bagaimana sikap jamaah masjid terhadap tradisi puji-pujian sebelum sholat dapat dilihat dari pendapat jamaah di masjid desa Giling Kabupaten Semarang dan Kelurahan Sumurboto Kota Semarang. Islam pedesaaan lebih akrab dikenal oleh orang yang melek huruf sebagai Islam konservatif. Walaupun kenyataannya istilah ini tidak dikenal oleh para kyai kampung yang senantiasa menjaga umatnya di akar rumput. Biasanya Islam di pedesaan masih sangat terikat dengan tradisi Jawa. Gending-gending (lagu-lagu) Jawa yang biasa mereka dengarkan dari radio ataupun dari pertujukan-pertunjukan begitu melekat di hati mereka.

Penelitian ini merupakan penelitian lapangan yang merupakan salah satu metode pengumpulan data dalam penelitian kualitatif yang tidak memerlukan pengetahuan mendalam akan literatur yang digunakan dan kemampuan tertentu dari pihak peneliti. Penelitian lapangan biasa dilakukan untuk memutuskan ke arah mana penelitiannya berdasarkan konteks.. Penelitian ini berusaha melihat sejauh mana sikap masyarakat muslim khususnya jamaah masjid/ musholla di perkotaan dan pedesaan terhadap praktik puji-pujian sebelum sholat. Penelitian dilakukan di dua desa yaitu Desa Giling Kecamatan Pabelan Kabupaten Semarang yang mewakili masjid pedesaan serta Kelurahan Sumurboto Kecamatan Banyumanik Kota Semarang yang mewakili daerah perkotaan.

Tulisan singkat ini akan mencoba menguraikan makna pujian, praktik pujian dan sikap jamaah masjid terhadap praktik pujian sebagai tradisi pesantren ini.. Tulisan ini didasari atas pengamatan di beberapa masjid pedesaan di desa Giling Kecamatan Pabelan Kabupaten Semarang dan di lingkungan perumahan kota Semarang. Dipilihnya desa Giling karena desa ini mewakili kultur desa santri yang cukup jauh dari pengaruh kota, sedangkan Kelurahan Sumurboto merupakan daerah yang dulunya perkampungan di wilayah selatan Kota Semarang yang baru mengalami perubahan sejak berdirinya kampus Universitas Diponegoro. Metode yang digunakan adalah observasi langsung pelaksanaan tradisi pujian 
di lokasi penelitian dirangkai dengan wawancara dengan pelaku pujian serta penelusuran pustaka yang terkait.

\section{Hasil}

Kata pujian berasal dari kata bahasa jawa "puji" yang artinya: memuji, kemudian diberi akhiran "an" yang artinya: pengakuan dan penghargaan dengan tulus atas kebaikan/ keunggulan sesuatu. Dalam Kamus Besar Bahasa Indonesia, kata "pujian" berasal dari kata dasar "puji" yang berarti pernyataan rasa pengakuan dan penghargaan yang tulus akan kebaikan (keunggulan) sesuatu, yang berarti juga do'a atau sembahyang, kemudian kata "puji" yang mendapatkan akhiran "an" menghasilkan kata "pujian" yang menunjukkan arti pernyataan memuji, doa bersama-sama pada petang hari untuk memuliakan Tuhan. Adapun kata "puji pujian" adalah perkataan memuji, memuji kebaikan, keunggulan dan lain-lain (Tim KBBI Pusat Bahasa, 2008: 1112).

Secara istilah pujian pujian itu berisi serangkaian kata baik yang berbahasa Arab atau berbahasa daerah yang berbentuk sya'ir berupa kalimat-kalimat yang isinya sanjungan untuk Allah dan Rasul-Nya, mengagungkan asma Allah, dzikir, do'a, shalawat, seruan atau nasehat yang dibaca pada saat di antara adzan dan iqamat. Istilah pujian sangat melekat pada komunitas santri khususnya orang NU. Oleh karenanya Muzakka (2006) memasukkannya ke dalam sastra pesantren. Dalam praktiknya, pujian bisa jadi kalimat yang mengandung pujian, lantunan șalawat Nabi dengan beragam nasyid-nya, ungkapan ajaran Islam atau pesan moral para ulama, meski dengan bahasa Jawa yang kental. Pujian dilakukan setelah ażan, sebelum shalat berjama'ah. Hal ini ditempuh karena ingin memanfaatkan waktu, daripada bercengkerama saat menanti datangnya imam jama'ah (Fatah, 2012: 202). Para makmum yang telah datang lebih dahulu dari imam dapat melantunkan pujian untuk berdoa, membaca șalawāt atas Nabi, dari pada membicarakan sesuatu yang tidak bermanfaat atau bahkan bisa mendatangkan dosa. Pelaksanaannya biasanya dipimpin oleh muadzin/ bilalnya dan ditirukan secara koor oleh para jamaah.

Kebiasaan pujian yang khususnya berada di tanah Jawa ini, dulunya dibawa oleh Wali Songo, terutama yang terkenal nyentrik dakwahnya di kalangan umat Islam Jawa yaitu Sunan Kali Jaga. Dalam dakwahnya Sunan menggunakan kesenian, diantaranya adalah wayang, gending dan berbagai alat tabuh-tabuhan. Dengan ketekunan dan kesabaran inilah masyarakat Jawa mengenal budaya-budaya Islam yang dilandasi oleh wali songo yang salah 
satunya adalah dengan puji-pujian, untuk menunjukkan syi'ar agama Islam dan sekaligus mengenalkan masjid. Dari situlah agama Islam baru dikenal oleh masyarakat.

Kehidupan manusia tidak bisa dipisahkan dengan seni. Bagi manusia seni merupakan alat untuk mengungkapkan pengalaman kehidupannya terhadap realitas kejiwaan yang sangat komplek. Dalam mengungkapkan pengalaman terhadap realitas jiwa, manusia mengunakan simbol yang berbeda. Pengalaman yang sederhana dan dapat digambarkan secara logikakan diungkapkan dengan bahasa yang terdiri dari susunan kata-kata maupun isyarat (bahasa tubuh). Sebaliknya, jika pengalaman terhadap realitas tersebut berfisat komplek, maka manusia cenderung mengepresikannya melalui seni.

Pujian merupakan ekspresi seni yang dihasilkan oleh komunitas pesantren. Hal ini dikarenakan sya'ir pujian di samping memiliki keindahan seni yang bernilai sastra, juga keindahan dari sisi suara atau musik karena dalam praktiknya, syair pujian itu dilantunkan dengan irama lagu-lagu yang nyaman didengar telinga.

Tradisi pujian tidak bisa dipisahkan dengan seni sastra keagamaan (Islam) Jawa khususnya yang berbentuk puisi yaitu singir (Jamil, 2010: 19), dalam bahasa Muzakka tradisi ini merupakan bentuk tradisi sastra pesantren karena berkembang di pesantren dan dipakai untuk pengajaran agama Islam (2009). Tradisi pujian dan singiran tersebut merupakan hasil dialog yang harmonis antara agama (Islam) di satu sisi dan budaya lokal (Jawa) di sisi lain (Ahmadi, 2000: 146-147). Dari dialog tersebut lahir kreativitas baru berupa seni sastra keagamaan Islam (sya'ir/ puisi) dan seni suara. Untuk mengekspresikan hasil dialog tadi diperlukan ruang dan waktu. Salah satu ruang dan waktu ekspresi yang telah mapan adalah tradisi pujian di masjid/ langgar. Di samping itu memang ada motivasi keagamaan yang didasari atas hadis Nabi, dari sahabat Anas, "tidak ditolak doa yang dipanjatkan antara azan dan iqamah (HR. Abu Dawud, at-Tirmiżì, Nasa'ī dan Ibnu as-Sunnī. Imam at-Tirmiżī berkomentar: hadis ini hasan sahih).

Hadirnya agama Islam di nusantara (Jawa) adalah salh satunya atas jasa para saudagar yang selanjutnya dalam tahap penyebarannya dijalankan oleh para pendakwah yang sufi (Azra, 2000). Penyebaran Islam oleh para sufi ini menjadikan Islam di Jawa bercorakkan tasawuf. Dalam eksistensinya Islam dengan corak sufistik mempengaruhi cara berfikir dan bertindak dalam mengekspresikan keislaman. Salah satu ekspresinya adalah munculnya seni sastra Islam (Jawa), yang salah satunya produknya adalah tradisi singiran dan pujian.

Menurut Clifford Geertz, agama pada dasarnya merupakan sistem kultural (budaya) yang memberikan makna dalam eksistensi manusia (Morris, 2003: 393). Berangkat dari 
pernyataan ini, dapat dikatakan bahwa tradisi pujian merupakan produk budaya, hasil dari agama Islam sebagai sebuah sistem budaya.

Tradisi puji-pujian ini sebenarnya sudah berkembang lama di Jawa. Semenjak jaman Ronggowarsito, Jawa sudah akrab dengan berbagai tembang seperti tembang gedhe, tembang tengahan dan tembang cilik. Tembang cilik ini dikenal dengan macapat . Tembang macapat adalah nyanyian tradisional Jawa yang pada setiap bait tembang macapat memiliki baris kalimat yang disebut dengan istilah gatra, dan setiap gatra memiliki sejumlah suku kata (guru wilangan) tertentu dan yang berakhir pada bunyi sajak akhir disebut sebagai guru lagu. Tembang macapat ini ada 11 macam antara lain mijil, dandanggulo, macapat, pangkur, Pucung dan lain sebagainya. Kemunculan tembang macapat diperkiraan pada akhir dari kepemimpinan Majapahit dan dimulainya pengaruh Walisanga.

Berbagai tembang ini sudah akrab di telinga masyarakat Jawa secara keseluruhan. Suasana yang menarik untuk didendangkan di sela-sela kesibukan mereka di sawah maupun di kebun. Sambil leyeh-leyeh mereka bisa uro-uro mendendangkan berbagai hal yang mereka lihat dan rasakan. Dari sini bisa diketahui betapa orang-orang Jawa sangat dekat dengan alamnya.

Kondisi yang seperti inilah yang kemudian dimanfaatkan oleh para wali penganjur Islam, seperti Sunan Bonan dan Sunan Kalijaga untuk memasuki tembang-tembang Jawa memiliki spirit Islam, sehingga nilai syiar Islam lebih membumi dan mudah dimengerti oleh para petani yang masih awam pengetahuannya tentang Islam. Selain itu irama puji-pujian biasanya juga diilhami oleh tradisi pembacaan kitab maulid seperti Al Barzanzy, Burdah, Dziba' dan yang saat ini populer Simtut Duror.

Isi puji-pujian itu berupa kalimat-kalimat yang mengandung dzikir, tasbih, takbir, tahlil, shalawat dan doa-doa dengan irama yang santun. Bacaan suci atau disebut kalimat tayyibah tersebut dirangkai dengan nasihat, doa, ajakan, larangan, dll dalam bahasa Jawa. Misalnya pujian yang berupa bacaan istighfar dirangkai dengan ajakan

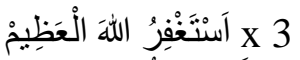

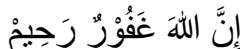

Gusti Alloh kulo nyuwun ngapuro

Gusti Alloh kulo nyuwun ngapuro

Sekatahahe dosa kulo

Dosa agung kelawan ingkang alit

Mboten wonten ingkang saged ngapuro

Mboten wonten ingkang saged ngapuro

Sanesipun Tuhan kang Moho Agung

Kang ngratoni sekathahe poro ratu 


\section{Nggih meniko Alloh asmane \\ Nggih meniko Alloh asmane \\ Kang kagungan sifat Rohman \\ Kang kagungan sifat Rohim}

Bacaan pujian bisa berupa bacaan yang berbahasa Arab seperti doa, kalimat tayyibah dan salawat saja, biasanya dirangkai dengan singiran berbahasa Jawa. Pujian biasanya dipimpin oleh orang yang mengumandangkan panggilan sholat (adzan) yang sering disebut mu'adzin/ bilal. Jamaah lain yang sudah datang di masjid duduk dan menirukan secara koor sampai datangnya imam dan sholat jamaah didirikan.

Desa Giling Kecamatan Salatiga adalah sebuah desa dengan kultur Jawa santri ala Nahdlotul Ulama. Hal ini ditandai masih berjalannya tradisi keagamaan seperti pengajian rutinan (yang dilakukan oleh ibu-ibu Muslimat dan berjanjen, yasinan bapakbapak), mujāhadah, nariyahan, haul dan pujian di masjid/ musholla. Selain tradisi tersebut, masih berlangsung juga tradisi slametan, kondangan/ bancaan (ruwahan, mitoni, penganten, sebelum sunat (tetak/ khitan), sebelum nikah, sor tanah), tahlilan (1-7 hari, nyatus/ 100 hari, mendak/ 1 tahun dan nyewul 1000 hari orang meninggal.

Desa yang terletak kira-kira $5 \mathrm{~km}$ di sebelah timur laut Kota Salatiga ini memiliki 1 masjid dan 3 langgar/ musholla (Masjid Annajah Giling, langgar kulon, langgar Krajan dan Langgar Tamparkeli). Kesemuanya masih itu melakukan pujian sebelum sholat. Biasanya muadzinlah yang memimpin pujian. Jamaah lain menirukan. Dahulu, lama pujian tergantung datangnya imam. Jika setelah ditunggu agak lama imam belum datang, biasanya akan dipanggil dengan pukulan kentongan dua kali. Namun semenjak tahun 2012 di masjid Annajah Desa Giling telah memasang penanda waktu jeda antara adzan dan iqamat yang dapat disetel kira-kira 10 - 15 menit. Ketika imam tidak juga datang, maka sholat dipimpin oleh siapa pun yang dianggap mampu di antara jamaah. Sementara di langgar Tamparkeli, Krajan dan Langgar Kulon, masih dengan tanda kentongan dua kali.

Bacaan yang dibaca di sekitar sholawat (seperti sholawat badar, sholawat Ibrahimiyah, sholawat nariyah, sholawat tunji, dll), istighfar, doa (doa sapu jagad, doa minta hujan, dll), tasbih, tahlil dan tahmid dirangkai dengan singiran bahasa Jawa yang isinya penanamn akidah, pujian kepada Rasul, peringatan mati, ajakan untuk sholat, dsb. Menurut para pemuka agama di desa itu pujian dilakukan karena waktu antara adzan dan iqamat adalah saat yang paling tepat untuk berdoa meminta apa pun. Supaya tidak monoton dan tidak membosankan dan supaya mempunyai daya tarik, maka pujian itu dilagukan. Lagunya pun bervariasi. Biasanya dilagukan seperti lagu-lagu maulid, namun beberapa pujian dilagukan dengan lagu nayian yang populer saat itu yang mereka dapatkan dari radio atau kaset tentunya dengan penyesuaian-penyesuaian, seperti lagu Es Lilin, Ilir-ilir, dll. 
Jika dilihat jamaahnya, desa Giling mayoritas beragama Islam ala Nahdlotul Ulama, dan tradisi pesantren melekat pada para pemuka agama mereka. Hampir tidak ada penolakan atas kegiatan ini. Namun yang terjadi pelaksanaan itu akhir-akhir ini agak memudar dari segi pelaku pujian. Hampir semua pujian di masjid dan langgar di Desa Giling dilakukan oleh orang tua. Sementara anak remaja dan muda sudah jarang sekali yang mau memimpin. Anakanak usia SD ada kalanya ikut, namun tidak sebanyak sekitar tahun 1980-an. Di samping itu jamaah yang mau mengikuti pujian tidak lagi sebanyak dulu. Yang paling banyak hanya saat solat Maghrib. Bacaan pujiannya pun saat ini monoton hanya solawat dan doa dalam bahasa Arab. Variasi singiran yang dulu biasa dilakukan orang tua yang berisi ajakan dan peringatan jarang bahkan tidak lagi dikumandangkan. Sementara banyak anak tidak hafal bunyi singiran tersebut. Hal ini cukup mengimbas pada kemampuan seni baca Al Quran anak-anak.

Tabel 1

Masjid Sikap Jamaah Masjid/ Langgar di Pedesaan

\begin{tabular}{|l|l|l|l|l|}
\hline No & Masjid & pujian & Tidak & keterangan \\
\hline 1 & Annajah & v & & \\
\hline 2 & Langgar Kulon & v & & \\
\hline 3 & Langgar Tamparkeli & v & & \\
\hline
\end{tabular}

Menurut Afifudin (60 tahun) imam masjid Annajah Giling, kebiasaan anak membaca pujian dan adzan itu akan berbanding lurus dengan kemampuan melagukan (tilawah) Al Quran. Saat ini susah mencari anak yang pandai melagukan Al Quran yang biasanya dibaca saat acara pembukaan kegiatan seperti pengajian, walimatul Ursy, dll.

Lain halnya situasi yang pada jamaah masjid di perkotaan. Hasil pengamatan di Masjid Al Muktashim Pondok Bukit Agung Sumurboto, Masjid Baitussalam Bukitsari, Masjid Al Azhar Banyumanik dan Masjid Al Falah Sumurboto menunjukkan hal yang berbeda. Masjid yang berada di bagian selatan Kota Semarang dahulunya memang masih kental dengan nuansa perkampungan, namun setelah kampus Universitas Diponegoro dibangun dan beroperasi, kawasan ini menjadi ramai dan tampak jelas nuansa perkotaaan.

Masjid Al Mu"tashim dan Masjid Baitussalam berada di kompleks perumahan elit, Bukitsari. Sementara Masjid Al Azhar Klentengsari Banyumanik dan Masjid Al Falah berada di perkampungan umum. Di empat masjid yang menjadi sampel penelitian ini terdapat perbedaan dalam menyikapi pujian. Hal itu dapat dilihat pada tabel 1 berikut

TABEL 2.

Sikap Jamaah Masjid di Komplek Perkotaan

\begin{tabular}{|l|l|l|l|l|}
\hline No & Masjid & pujian & Tidak & keterangan \\
\hline 1 & Al Mu'tashim & & v & Dulu, sekarang tidak \\
\hline
\end{tabular}




\begin{tabular}{|l|l|l|l|l|}
\hline 2 & Baitussalam & V & & Kadang-kadang \\
\hline 3 & Al Azhar & & V & moderat \\
\hline 4 & Al Falah & V & & NU \\
\hline
\end{tabular}

Masjid Al Mu'tashim yang berada di lingkungan perumahan menengah dulu pernah melakukan pujian karena semua marbotnya memang berasal dari desa di Kabupaten Magelang dan berlatar belakang NU, sementara takmir masjid dan para warga mayoritas awam dalam hal agama Islam. Akibatnya saat para marbotnya mentradisikan pujian, awalnya warga menerima. Namun setelah muncul kajian yang diampu oleh alumni Timur Tengah dan LIPIA Jakarta, maka kegiatan pujian dilarang. Demikian pula kebiasaan pembacaan tarhim menjelang solat Subuh dan bacaan wirid secara keras (jahr) dilarang. Menurut ketua takmir, hal itu disebabkan tidak ada tuntunannya di dalam agama Islam, di samping itu pujian dianggap mengganggu orang yang sedang solat sunnah dan berdoa serta membuat bising kompleks perumahan. Sebagian jamaah yang dahulunya di kampung terbiasa melantunkan pujian akhirnya terpaksa tidak melaksanakannya. Sekali pun di belakang mereka menggerutu dengan keputusan ini. Namun lama kelamaan sudah terbiasa. Akibat selanjutnya bagi para remaja dan anak-anak, hampir semuanya tidak bisa melantunkan pujian ini.

Di Masjid Al Azhar lain lagi. Sejak awal masjid yang didirikan oleh Yayasan Pesantren Islam ini memandang bahwa pujian sebelum sholat akan mengganggu para jamaah lain yang akan mendirikan sholat atau berdzikir. Sekalipun marbot masjid dan sebagian jamaah berlatar belakang NU. Akhirnya jamaah yang kebanyakan dulunya di kampung biasa melantunkan pujian, setelah pindah tidak lagi bisa mendengar dan mengikuti pujian. Para jamaah yang tua rata-rata merindukan suasana pujian itu. Untuk jamaah remaja dan anakanak, mereka sama sekali tidak mengetahui tentang pujian ini apa lagi hafal dan melafakan.

Masjid Baitussalam berada di kompleks Perumahan elit Villa Bukit Mas Bukitsari. Masjid ini sampai saat ini masih mempraktikkan pujian sebelum sholat. Hal ini karena ketua takmir dan marbotnya semua adalah NU dan berlatar belakang pesantren. Jamaah menerima karena kajian yang dilakukan di masjid dikontrol oleh Ketua Takmir sehingga tidak kemasukan faham lain yang membid'ahkan perilaku pujian tersebut.

Sementara Masjid Al Falah Sumurboto yang berada di perkampungan Sumurboto dan terdapat kompleks Pondok Pesantren Mahasiswa Al Falah sampai saat ini tetap mengumandangkan puji-pujian. Menurut para santri yang hampir semuanya adalah para mahasiswa yang berasal dari kampung dengan tradisi kampung, kegiatan pujian itu memang tradisi yang baik, ada dasarnya dalam hadist serta banyak manfaatnya. Mereka merasakan banyak manfaat antara lain untuk mengeksplorasi kepiawaian seni suaranya, melatih keberanian dan kebersamaan.

Menurut pimpinan pondok pesantren Al Falah, KH Makmun, berpijak dari isi baca'an dalam pujian itu berupa dzikir, sholawat, dan nilainya yang mengandung banyak dakwah 
Islamiyah, maka hukum mengamalkan pujian-pujian sebelum sholat berjama'ah adalah mubah, bahkan sunnah, sebab memuji kepada Allah merupakan suatu anjuran yang harus dilakukan setiap waktu. Beliau memberikan alasan dengan mengutip dari beberapa kitab seperti kitab al-Adzkar al-Nawawiyyah,Bughyatul Mustarsyidin, dan Irsyadul Mu'minin.

Intinya do'a yang dipanjatkan antara adzan dan iqomah tidak akan ditolak, dzikir sebagaimana membaca (al-Qur'an) jelas disunnahkan dengan dalil shorihnya ayat dan hadits, dan mengeraskan suara dzikir itu boleh selama tidak dikhawatirkan riya' dan tidak mengganggu orang sholat, dan hukumnya boleh melantunkan sebuah sya'ir yang di dalamnya berisi pujian, nasihat, pelajaran budi pekerti dan ilmu yg bermanfaat di dalam masjid, dan itu pasti dilakukan dengan suara keras dalam perkumpulan (secara bersama-sama).

Terkait dengan pembacaan dzikir dan pujian sebelum sholat ini, KH Muhyiddin Abdusshomad, menerangkan bahwa membaca dzikir dan syair sebelum pelaksanaan shalat berjama'ah, adalah perbuatan yang baik dan dianjurkan. Anjuran ini bisa ditinjau dari beberapa sisi. Dari sisi dalil terdapat hadis yang menyatakan bahwa dahulu pada masa Rasulullah Saw. para sahabat juga membaca syair di masjid. Dari hadis melantunkan syair yang berisi puji-pujian, nasihat, pelajaran tata krama dan ilmu yang bermanfaat di dalam masjid adalah sesuatu yang bukan dilarang oleh agama, dengan kata lain hukumnya adalah mubah.

Dilihat dari sisi syiar dan penanaman akidah umat, selain menambah syiar agama, amaliah tersebut juga merupakan strategi yang sangat jitu untuk menyebarkan ajaran Islam di tengah masyarakat. Karena di dalamnya terkandung beberapa pujian kepada Allah SWT, dzikir dan nasihat.

Dari aspek psikologis, lantunan syair yang indah itu dapat menambah semangat dan mengkondisikan suasana. Dalam hal ini, tradisi yang telah berjalan di masyarakat tersebut dapat menjadi semacam warming up (persiapan) sebelum masuk ke tujuan inti, yakni shalat lima waktu. Selain ketiga manfaat tersebut, syair dan dzikir yang dilantunkan sebelum shalat berjamaah bisa mengobati rasa jemu sembari menunggu waktu shalat jama'ah dilaksanakan. Juga agar para jama'ah tidak membicarakan hal-hal yang tidak perlu ketika menunggu shalat jama'ah dilaksanakan.

Berdasarkan dalil dan argumen di atas, beberapa jamaah masjid tetap melanggengkan tradisi melantunkan dzikir dan syair sebelum shalat berjamaah di masjid dan mushala. Namun begitu, perlu digarisbawahi, bahwa amaliah ini tergantung pula pada situai dan kondisi, tidak dibenarkan apabila sampai mengganggu orang yang shalat dan membuat bising masyarakat di sekitar masjid atau mushala. 


\section{Simpulan}

Dari pembicaraan di atas dapat disimpulkan bahwa tradisi pujian adalah pembacaan sholawat, tasbih, doa, dzikir yang dilaksanakan antara waktu setelah azan dan iqamat sebelum solat berjamaah di masjid/ langgar. Di dalam pujian terkandung muatan bacaan kalimat yang baik serta nasihat yang baik kepada manusia dengan dilagukan. Pujian merupakan salah satu tradisi sastra pesantren. Sikap masyarakat terhadap praktik pujian ini ada dua macam yaitu menerima dan menolak. Masyarakat yang menerima berpendapat bahwa tradisi pujian adalah amalan yang baik dan dicontohkan Nabi yang berpahala, juga untuk mengingatkan masyarakat dengan pesan-pesan dakwah. Mereka biasanya dari kalangan NU. Sementara yang menolak beralasan bahwa tradisi ini tidak ada tuntunannya di zaman Rasulullah, selain itu juga pujian dianggap mengganggu kekhusukan jamaah lain yang akan mendirikan solat sunnah dan berdoa, serta menimbulkan kebisingan lingkungan, sehingga dianggap sebagai bid'ah yang buruk dan harus ditinggalkan. Di masyarakat yang menerima tradisi pujian sebelum sholat pun tradisi pujian ini dirasa mulai memudar dari sisi jumlah peminatnya maupun dari sisi materi pujiannya.

\section{Daftar Pustaka}

Ahmadi, Asmoro, 2000, Korelasi Islam dan Jawa dalam Bidang Sastra dalam Islam dan Kebudayaan Jawa, Semarang: Gama Media dan Pusat Kajian Islam dan Budaya Jawa IAIN Walisongo.

Azra, Asyumardi, 2005, Jaringan Ulama: Timur Tengah dan Kepulauan Nusantara Abad XVII dan XVIII, Jakarta: Republika

Fatah, Munawir Abdul, 2012, Tradisi Orang-orang NU, Yogyakarta: Pustaka Pesantren

Hamidi, Jazim dan Asyhadri Abta. 2005. Syi 'iran Kiai-Kiai. Yogyakarta: Bentang

Hutomo, Saripan Sadi. 1991. Mutiara yang Terlupakan: Pengantar Studi Sastra Lisan HISKI Komda Jatim.

Jamil, M. Mukhsin \& Kawan-kawan , 2010, Syi'iran dan Transmisi Ajaran Islam di Jawa, Semarang: Walisongo Press.

Morris, Brian, 2003, Antropologi Agama: Kritik Teori-teori Agama Kontemporer: diterjemahkan oleh Imam Khoiri, Yogyakarta: AK Group.

Muzakka, Moh. 2006. "Puisi Jawa Sebagai Media Pembelajaran Aternatif Di Pesantren (Kajian Fungsi Terhadap Puisi Singir)" Makalah Kongres Bahasa Jawa IV Tahun 2006. 
Nasr, Sayyed Hossein, 1994, Spiritualitas dan Seni Islam diterjemahkan oleh Sutejo dari Islamic Art and Spirituality, Bandung: Mizan.

Priyanto, Syadhak Arqi (2009) "Tradisi Pujian Menjelang Sholat Lima Waktu di Mushala Baitul Muttaqin Kelurahan Bangunsari Kecamatan Dolopo Madiun”.

Rifai, Muhammad Yunus Bakhtiar, 2013. "Makna Tradisi Pujian Bagi Masyarakat Dusun Kajangan Kelurahan Sonorejo Kabupaten Blora (Suatu Pendekatan Antropo-Sufistik)" . Tesis Magister Studi Islam Pascasasrjana IAIN Walisongo Semarang

Tim Penulis. 2008. Kamus Besar Bahasa Indonesia. Jakarta” Balai Pustaka. 